\title{
The influential factors of business development among SMEs in the Food Industry of the GCC Region
}

\author{
Bandar Fahad Alharbi \\ Ahmed Al-Ashaab \\ Cranfield University, UK
}

\section{Keywords}

Small and Medium-sized Enterprises (SMEs), Business Development, Business models, Business Model Canvas (BMC), Gulf Cooperation Council (GCC), the Food sector

\begin{abstract}
SMEs are the core engine of most economies around the world. Empowering SMEs with the right tools, especially those tools utilized to formulate business models would help the ventures to thrive more successfully. This study aims to provide such business development support tools to the food sectors SMEs of the GCC. This paper presents the results of an on-going research, part of which is investigating the factors influencing business development decision making, among SMEs operating in the food industry of the Gulf Cooperation Council (GCC). To that end, the paper conducts an extensive literature review on the topic, which is followed by an industrial field study, and analysis of the data obtained. The field study involved 36 companies within the food industry of the GCC region.

The findings from this study show that the SMEs in the food industry in the GCC region will need to have an effective business model in order to successfully run or grow their businesses. The initial result of this research shows that the business model canvas is the most suitable for SMEs in the GCC food sector. Furthermore, from the field study, a total of eleven influential factors have been identified, and these factors influence the approach to the business development process and the eventual success of such business development activities. Finally, from the eleven factors, three themes were established. These themes showed the relationship between the influential factors and the BMC; the themes were the value proposition design, customer segmentation and business planning.

In conclusion, it was identified that the major challenge the food SMEs face is that of establishing a product-market fit in the development of their products and services. Product market fit as a challenge in the GCC is associated with the rapid geopolitical and social changes being experienced in the region. Hence, leading to changes in the demand and delivery of food products. Product market fit challenge is also linked to the fundamental weakness of the BMC identified in the study. Therefore, further research is required to see how the BMC can be enhanced, to make it more effective to the specific needs and structure of the GCC market environment. To do this will require to capture and incorporate the knowledge from this study and those from successful food SMEs into a single enhanced BMC.
\end{abstract}

Corresponding author: Bandar Fahad Alharbi

Email addresses for the corresponding author: bandar.alharbi@cranfield.ac.uk

First submission received: $4^{\text {th }}$ March 2020

Revised submission received: $24^{\text {th }}$ April 2020

Accepted: 27th April 2020

\section{Introduction}

The study seeks to identify the influential factors affecting business development among SMEs operating in the food industry of the Gulf Cooperation Council (GCC). Most businesses in the GCC are now looking to innovation-led strategic transformations as well as the adoption of the latest and simplest business models to help them improve their business processes (The World Bank, 2015). This shift in approach and the demand for a more effective business model is mainly motivated by an ever-increasing global competition in the food sector, as well as advancements in technology. Consequently, it has become necessary to understand the influential factors that affect business development, together with similar other factors that guide the design of a business model. The identified factors can then be considered by the SMEs in the GCC to achieve their desired growth and sustainability. 
The environment in the GCC region is considered unsuitable to agricultural and food production due to its extreme climatic conditions. As a result, more than $90 \%$ of the region's food and beverage needs are imported to meet its domestic demand (FAO, 2002). Additionally, the GCC region has been experiencing a change in lifestyle over the past few decades, mainly due to urbanisation and busy working families, and this has also contributed to an increase in demand for high-value processed food. Furthermore, the region has the fastest-growing tourism industry in the world, and this has also caused a higher demand for food and its consumption. Consequently, the local food industries are having to play catch-up and need to reconsider their strategies to meet such increasing demands.

The main aim of this research is to identify the key factors that should be considered by Food sectors SMEs, so as to develop a more effective business model. These factors can then be further investigated by capturing the relevant pieces of related knowledge, and which can then be presented as a model that can be used to guide the SMEs with their business development. Such a model should be able to help the SMEs achieve growth, profitability, and expansion to new markets. This paper presents the results from the on-going research describing the influential factors that significantly impact the decision making of SMEs in their business development. The paper identifies such influential factors through extensive literature review and the data analysis of industrial field study in the GCC region. The authors believe that these influential factors are also the source of the knowledge that should be captured, to make up a holistic business model that will aid SMEs to plan for business sustainability and growth accurately.

\section{Research Methodology}

The analysed data were collected in three phases. Phase one was a review of the existing literature on the influential factors and challenges of business development. In phase two, a questionnaire survey was developed to collect primary data from an industrial field study on SMEs operating in the food processing sector in the GCC, this is followed by phase three, where an analysis of the data captured from the industrial field study was analysed. Finally, a list of all the key influential factors and detailed explanation of each of them is presented. These factors are further grouped into themes, to identify the main area to focus on, so as to help the Food sector SMEs in the GCC improve the effectiveness of their business development activities.

The sample of the field study consists of 36 companies, whose owners and top directors were interviewed through utilising a semi-structured questionnaire. The questionnaire was developed based on the finding from the literature review. Sampled companies serve as a representative of the food sector across different states in the GCC region, and with employees ranging between 50 to 200 only. The study was conducted via face-to-face interviews. In each case, the participants had experience ranging between 5 to 20 years in the sector.

\section{Review of the related literature}

\section{Overview of business development and business models}

" Business development is defined as the creation of long-term value for an organisation, from its customers, markets, and relationships" (Sørensen 2012). This is achieved by intentionally pursuing strategic opportunities for the organisation, such as by cultivating partnerships or other commercial relationships, or by identifying new markets for products or service (Rainey, 2010). 'Value' to an organisation, in this context, refers to more than just assets, revenue or shareholders value; it also includes other elements such as human capital, knowledge, prestige, image, business relationships, social involvement and social responsibilities.

Therefore, in this paper, business development is considered as the strategic process of identifying ongoing and future opportunities, minimising risks, creation of a flexible environment for success, and being prepared for continuing changes.

A typical business development process is a challenging decision process, as various conflicting factors need to be considered at the same time. For example, how to find a balance between issues relating to competitive advantage and those relating to new business opportunities. Such decision making and processes as they relate to business development factors are known as the 'business model design' (Kajanus et al., 2014). 
A business model offers a structured approach to business development. It offers a comprehensive framework that addresses all the necessary business elements of that particular business context; at the same time, it shows how to manage the interrelations of the elements (Osterwalder \& Pigneur, 2010).

Simply put, a business model is a tool that reflects the business development activity of a firm (Drakulevski and Nakov, 2014). The business model helps to address how the various elements of business development activities are strategically selected, aligned, and communicated to the relevant stakeholders (Sørensen 2012). Business models can also be used by an organisation to fulfil various other functions. Some of these functions include the understanding and communication of the business logic. Business models can also be sued to analyse, manage, prospect and even patent such business logic (Osterwalder et al., 2005). By using a business model, even new players in a sector can expertly be guided in business development (D'Souza, 2016).

It is essential to point out that business development activities sometimes even transcend the focal firm and spans beyond its boundaries, encompassing other firms and players (Zott and Amit, 2010). Thus, despite a firm's centric view of its business model, the firm's business development approach has to deliberately integrate with other associated third parties' activities into its business model. Consequently, the business model, in this sense, can be used to adequately appropriate a share of the value captured to the other partners in the activity system (value-creating activity).

'Activity' in the context of business model, refers to 'the engagement of human, physical and/or capital resources - of any party to the business model (the focal firm, end customers, vendors, etc.), to serve a specific purpose towards the fulfilment of the overall business objective'. Likewise, an activity system in this context refers to 'a set of interdependent organisational activities, centred on the focal firm, including those activities conducted by its partners, vendors, customers, etc.' (Zott and Amit, 2010).

Presently, several business models are available; In the author's opinion, it is essential to compare the available business models and identify the most suitable for the food processing SMEs in the GCC. The main reason for this is to identify the best model that will help the SMEs to capture, understand, communicate, design, analyse and (if necessary) change the business logic of their firm towards growth and sustainability.

Various authors in the literature have suggested different types of business models. These models differ in terms of their building blocks, which are also called elements or components.

Combining components helps to define the logic of how a business creates value for its customers, and also how it captures value for itself. Given the vast difference in the types of elements in the available models, it is also necessary for this study to identify what elements should belong to a business model. The matrix in Table 1 shows the various available business models in literature with their authors, and also the types of components or elements these authors have considered. The matrix further illustrates how high or low each component has been adopted generally in business model literature. The authors were selected based on a search on business model components in different journals from 2000 to 2017. The most highly cited were considered, and a review was further carried out to ascertain their suitability for this purpose. This resulted in the selection of the final 14 studies for this research.

From Table 1, it can be seen that the components most referred to by the various authors are those regarding value proposition, market offerings and resources. In light of the most important components and bearing in mind the key aim of the business model required for this study, four of the models put forward are considered as the best that fit the criteria for this study. They are the Business Model Canvas of Osterwalder \& Pigneur (2010), Kaplan (2012), Chesbrough and Rosenbloom (2002), Johnson et al., (2008) and Osterwalder et al., (2005). 
Table 1: Components analysis of different business model based on literature

\begin{tabular}{|c|c|c|c|c|c|c|c|c|c|c|}
\hline $\begin{array}{l}\text { Component } \\
\text { Author }\end{array}$ & Strategy & Resources & Network & Customers & $\begin{array}{c}\text { Market } \\
\text { Offering (Value } \\
\text { Proposition) }\end{array}$ & Revenue & Key activity & Procurement & Finances & $\begin{array}{c}\text { The spectrum } \\
\text { of the } \\
\text { Components }\end{array}$ \\
\hline Hamel (2000) & $\begin{array}{l}\text { Core Strategy, } \\
\text { Strategic } \\
\text { Resources }\end{array}$ & & $\begin{array}{l}\text { Value } \\
\text { Network }\end{array}$ & $\begin{array}{l}\text { Customer } \\
\text { Interface }\end{array}$ & & & & & & Low \\
\hline $\begin{array}{l}\text { Chebrough } \\
\text { and } \\
\text { Rosenborg } \\
(2002)\end{array}$ & $\begin{array}{l}\text { Competitive } \\
\text { Strategy }\end{array}$ & Value Chain & Value Network & Market Segment & Value proposition & & & & $\begin{array}{l}\text { Cost } \\
\text { Structure } \\
\text { Profit } \\
\text { potential }\end{array}$ & High \\
\hline Yip (2004) & $\begin{array}{l}\text { Scope } \\
\text { Differentiations }\end{array}$ & & & $\begin{array}{l}\text { Nature of } \\
\text { customers, } \\
\text { Channels }\end{array}$ & $\begin{array}{l}\text { Value } \\
\text { Proposition } \\
\text { Nature of } \\
\text { Outputs }\end{array}$ & & $\begin{array}{l}\text { How to } \\
\text { transform } \\
\text { inputs } \\
\text { (including } \\
\text { technology) }\end{array}$ & & & High \\
\hline Morris (2005 & $\begin{array}{l}\text { Model of } \\
\text { differentiation, } \\
\text { Investors' } \\
\text { intentions }\end{array}$ & $\begin{array}{l}\text { Internal } \\
\text { capabilities }\end{array}$ & & $\begin{array}{l}\text { Market } \\
\text { segments }\end{array}$ & Offering & & & & $\begin{array}{l}\text { Economic } \\
\text { factors }\end{array}$ & High \\
\hline $\begin{array}{l}\text { Osterwalder } \\
\text { et al., (2005) }\end{array}$ & & & $\begin{array}{l}\text { Partner } \\
\text { Network }\end{array}$ & $\begin{array}{l}\text { Target } \\
\text { Customer, } \\
\text { Distribution } \\
\text { Channel, } \\
\text { Relationship } \\
\text { Value } \\
\text { Proposition }\end{array}$ & $\begin{array}{l}\text { Value } \\
\text { Proposition }\end{array}$ & $\begin{array}{l}\text { Revenue } \\
\text { Model }\end{array}$ & $\begin{array}{l}\text { Value } \\
\text { Configuration }\end{array}$ & & $\begin{array}{l}\text { Cost } \\
\text { Structure }\end{array}$ & High \\
\hline $\begin{array}{l}\text { Al-Debei et } \\
\text { al., (2008) }\end{array}$ & & & $\begin{array}{l}\text { Value } \\
\text { Network }\end{array}$ & & $\begin{array}{l}\text { Value } \\
\text { Proposition } \\
\text { Value } \\
\text { architecture }\end{array}$ & & & & $\begin{array}{l}\text { Value } \\
\text { Finance }\end{array}$ & Low \\
\hline $\begin{array}{l}\text { Deml and } \\
\text { Lecocq (2010) }\end{array}$ & & $\begin{array}{l}\text { Resources \& } \\
\text { Competenci } \\
\text { es }\end{array}$ & & & $\begin{array}{l}\text { Proposition for } \\
\text { Value Delivery }\end{array}$ & & $\begin{array}{l}\text { Organization } \\
\text { Structure }\end{array}$ & & & Low \\
\hline $\begin{array}{l}\text { Johnson } \\
\text { (2008) }\end{array}$ & & $\begin{array}{l}\text { Key } \\
\text { Resources }\end{array}$ & & & $\begin{array}{l}\text { Customer Value } \\
\text { Proposition }\end{array}$ & $\begin{array}{l}\text { Profit } \\
\text { Formula }\end{array}$ & Key Process & & & Moderate \\
\hline
\end{tabular}

www.jbrmr.com A Journal of the Centre for Business \& Economic Research (CBER) 


\begin{tabular}{|c|c|c|c|c|c|c|c|c|c|c|}
\hline $\begin{array}{l}\text { Osterwalder } \\
\text { and Plgneur } \\
(2010)\end{array}$ & & $\begin{array}{l}\text { Key } \\
\text { Resources }\end{array}$ & Key Partners & $\begin{array}{l}\text { Customer } \\
\text { Relationships, } \\
\text { Channels, } \\
\text { Customers } \\
\text { Segments }\end{array}$ & $\begin{array}{l}\text { Value } \\
\text { Proposition }\end{array}$ & $\begin{array}{l}\text { Revenue } \\
\text { Streams }\end{array}$ & Key Activities & & $\begin{array}{l}\text { Cost } \\
\text { Structure }\end{array}$ & High \\
\hline Kaplan (2012) & & & & & Value Delivery & Value capture & value creation & & & Low \\
\hline $\begin{array}{l}\text { Baden Fuller } \\
\text { and } \\
\text { Mangetmatin } \\
(2013)\end{array}$ & & & $\begin{array}{l}\text { value chain } \\
\text { and linkages }\end{array}$ & customers & $\begin{array}{l}\text { customer } \\
\text { engagement }\end{array}$ & $\begin{array}{l}\text { monetizatio } \\
\mathrm{n}\end{array}$ & & & & Moderate \\
\hline $\begin{array}{l}\text { Erwin Fielt } \\
(2014)\end{array}$ & & & $\begin{array}{l}\text { organizational } \\
\text { architecture }\end{array}$ & customer, & $\begin{array}{l}\text { value } \\
\text { proposition, }\end{array}$ & economics & & & & Moderate \\
\hline $\begin{array}{l}\text { Reim et al., } \\
\text { (2015) }\end{array}$ & & & & & value delivery & $\begin{array}{l}\text { value- } \\
\text { capture } \\
\text { mechanisms }\end{array}$ & Value creation & & & Low \\
\hline $\begin{array}{l}\text { Roome and } \\
\text { Louche (2016) }\end{array}$ & & & $\begin{array}{l}\text { value } \\
\text { network, }\end{array}$ & & $\begin{array}{l}\text { value } \\
\text { proposition }\end{array}$ & $\begin{array}{l}\text { value } \\
\text { capture }\end{array}$ & $\begin{array}{l}\text { value creation } \\
\text { and delivery }\end{array}$ & & & Moderate \\
\hline $\begin{array}{l}\text { Intensity of } \\
\text { use }\end{array}$ & Low & Moderate & High & High & High & High & High & Low & Moderate & \\
\hline
\end{tabular}


Previous authors have compared the business models on different effectiveness and efficiency factors. Some of such studies include Lucassen et al. (2012), Hoffmann (2013), and Aarntzen (2016). In these studies, authors considered the effectiveness of these models as the extent to which they successfully communicate and captures the entirety of the business models.

The most common criteria used by the authors for assessing the effectiveness of business models include:

1. Acceptance: the degree of utilisation of the framework in business and academia

2. Explicit Modelling Method: provides instructions that are explicitly defining the approach

3. Method Efficacy: the instructions are easily translated into practice.

Different authors also use several other criteria.

In this study, some of these are selected to compare the most common business models in the literature, as shown in Table 2. The criteria are assessed as High, Medium and Low comparative to each other, according to the number of components they have, or based on how they are used in the industry. Again, they are labelled as 'yes' or 'no' depending on if they measure up to the criteria.

In the end, the best business model is highlighted based on how well they satisfy the various criteria compared to the others (spectrum of effectiveness).

Table 2: Comparative analyses of business models

\begin{tabular}{|c|c|c|c|c|c|}
\hline No & Criteria & $\begin{array}{l}\text { BMC by } \\
\text { Osterwalder } \\
(2010)\end{array}$ & $\begin{array}{l}\text { Kaplan story } \\
\text { elements (2012) }\end{array}$ & $\begin{array}{l}\text { Business model } \\
\text { elements by } \\
\text { Johnson et al. } \\
(2008)\end{array}$ & $\begin{array}{l}\text { Business model } \\
\text { functions by } \\
\text { Chesbrough and } \\
\text { Rosenbloom } \\
(2002)\end{array}$ \\
\hline 1 & Number of Components & High & Low & Medium & Medium \\
\hline 2 & Include key components & Yes & Yes & Yes & Yes \\
\hline 3 & Visual representation & Yes & Yes & Yes & Yes \\
\hline 4 & Method of Evaluation & No & No & No & No \\
\hline 5 & used for all industries or in all sectors & Yes & Yes & Yes & $\begin{array}{l}\text { No (Mainly } \\
\text { technical } \\
\text { innovations) }\end{array}$ \\
\hline 6 & Guide for implementation & Yes & No & Yes & No \\
\hline 7 & Adoption in industry & High & Low & Medium & Low \\
\hline 8 & Applicable to SMEs & Yes & Yes & Yes & Yes \\
\hline 9 & Ease of use & High & Low & Low & Low \\
\hline \multirow[t]{2}{*}{10} & Simulate creativity & medium & Low & Low & Low \\
\hline & Spectrum of effectiveness & Best & Good & Average & Least \\
\hline
\end{tabular}

As can be seen from the analysis in Table 2, the Business Model Canvas is the most encompassing of the key criteria, when compared to the other frameworks. Its key weakness is in stimulating creativity. However, this as can be seen to be low within all the frameworks.

Not surprisingly, the business model Canvas is now the most widely used business model tool in both industry and academia. It has also been adopted in a wide variety of industries around the world (Hoffmann, 2013).

\section{Different applications of the business model canvas}

The Business Model Canvas (BMC) created by Osterwalder and Pigneur (2010) is presently the most popular business model available, and it has become standard amongst practitioners in the design (or redesign) of business models (Kajanus et al., 2014). The BMC's popularity has made it the focus of many academic studies (such as Coes, 2014; Golnam et al., 2014; and Gutiérrez and Borreguero, 2016). Several reasons are pointed to as the reason for its wide appeal among practitioners; key among them include the graphic representation it offers (Hoffman, 2013; Massa and Tucci, 2013), its focus on value (Coes, 2014) and its simplicity and ease-of-use (Gutiérrez and Borreguero, 2016). 
In Wrigley and Straker's (2016) assessment of the BMC, they used BMC to investigate innovation practices within a range of diverse companies. The BMC formed both parts of the research methodology and the research outcome. They concluded that the BMC was a tool that can be used as a "methodology for identifying and developing opportunities for business model innovation". Hoffmann's (2013) study, specifically observed the importance of the 'visualisation of business development elements' that is offered by the BMC. He explained that the visualisation effect helps to effectively communicate knowledge and stimulate creativity. It can also help in managing ongoing developments efforts, as the organisation have a snapshot view of its business model at any instant and can see any area that needs to be improved. Aarntzen (2016) studied the use of business model frameworks, especially among SMEs. He observed that the BMC is also the most widely used among industries of all sizes, including SMEs.

Despite the wide use of the BMC, other scholars have identified and criticised the limitations of the BMC (such as Chesbrough and Rosenbloom, 2002; Solaimani and Bouwman, 2012; Kraaijenbrink, 2012; Ching and Fauvel, 2013; and Jukova et al., 2019). The BMC is criticised for existing in isolation, and for lacking a detailed definition towards implementation. Other authors also recommended that the BMC should also consider strategy at the same time as the other business model elements, jointly integrated, as one holistic business development approach.

Therefore, for this study, the BMC needs to be further assessed, to see if it needs to be modified or customised, to make it more suitable to the needs of the food industry SMEs in GCC.

\section{SMEs business development and business performance (Growth)}

Scholars such as Achtenhagen et al., (2017) and Kumar (2017) have used different approaches to identify the factors affecting the performance and growth of small firms. However, there are considerable variations in the results of previous researches. As early as the 1950s, researchers started studying business development and business growth. They suggested that business performance can be assessed in terms of an increase in sales, numbers of employees, assets and/or profit (Kor et al., 2016). This provided an early theorization of business development. O'Cass and Sok (2013) defined business development and business growth, particularly as they relate to SMEs; they explained that business development and growth refers to a firm meeting or exceeding its performance goals. These can be financial goals (such as profitability, sales, revenue, and financial goals) and non-financial goals (such as intensified customer satisfaction).

Some scholars have attempted to list the factors that affect the growth of SMEs (Storey, 1994; Hsu et al., 2013). Some of the factors identified include the characteristics of the entrepreneur, available resources, and the firm's strategy. However, there appears to be no unified pattern, and rather, the evidence points towards a complex set of interrelated factors that affect small business growth. Furthermore, all of these factors need to be taken into account holistically.

Consequently, various authors have attempted to identify the growth paths among SMEs. Table 3 summarises the findings as reported in the literature. 
Table 3: Growth paths among SMEs

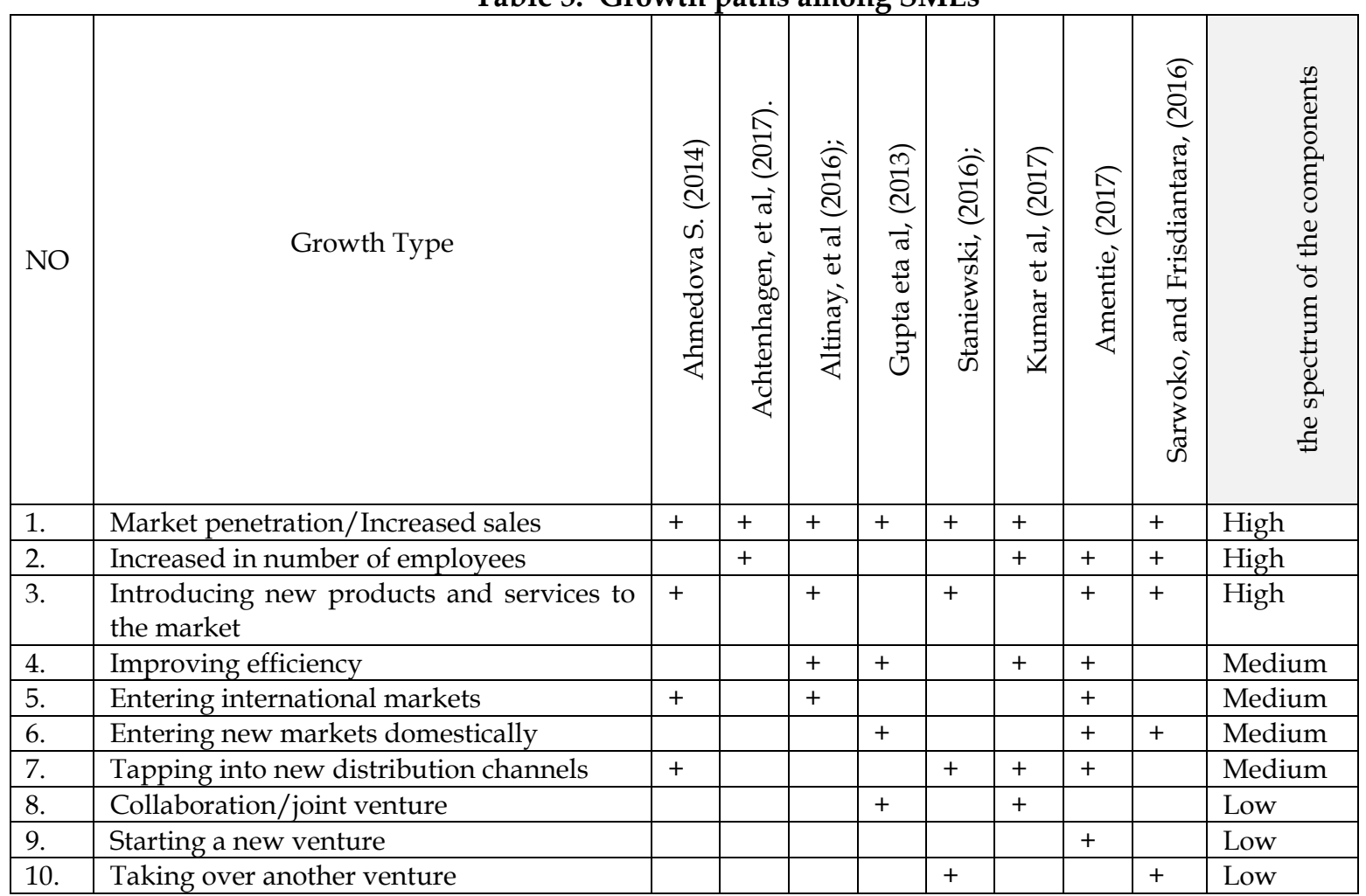

The authors have all reported varying degree of influence of the different growth path on SMEs business development. Nevertheless, Market penetrations/increase in sales and number of employees are considered by most authors as the most important type of growth. According to Nason and Wiklund (2015), an increase in sales is the most common performance indicator among entrepreneurs.

According to Achtenhagen, et al., (2017), market penetration or increase in sales is defined as the ability of the company to successively expand its sales, through in-house resources and activities, without necessarily having to engage in other growth modes such as acquisitions of other firms.

In order to achieve the desired growth of their businesses, SMEs in the food sector needs to have a business development model to help with balancing the different business elements, especially as different types of the business model are available for different purposes. In this research, the business model needs to help the firm to achieve whichever of the growth paths mentioned in Table 3 that a firm desire to pursue. Presently, there is no available business model that is good enough for all of them. Therefore, there is a need to modify the business model canvas so that it can be more suitable as a business model so that it can guide SMEs in the food sector of the GCC to meet their growth aspirations.

However, other factors also affect the ability of a firm to grow. Before an organisation can successfully use business modelling tools, they also need to be aware of these different internal and external influential factors. These factors are the focus of the next section.

\section{Influential factors on business development in SMEs}

Table 4 has been arranged as a matrix of literature/references published between 2008 to 2019 . It includes the key influential factors mentioned in the literature, such as value proposition, profit and market size. Among these factors, those that are mentioned more than four times are considered high, while those below four and up to two factors are considered medium. Those mentioned two times and less are among the authors considered as low.

As can be seen from Table 4, the most highly cited factors include a value proposition, profit, competition, market size, and entrepreneurial competencies. These make up the most important factors to consider in business development.

For example, profitability, which is considered one of the most influential factors for SME growth, can be explained to offer the base for a stable, resilient company, which can develop over 
time, generating value with which it can finance its expansion, from its accumulated profits (Achtenhagen et al., 2017).

Nevertheless, some factors from Table 4 are considered worth exploring, despite having a low mention in the literature reviewed. For example, the author believes the following are also important factors but have not been well explored by the literature:

- Networks Partners- networks are crucial in the international expansion of SMEs, especially internationally and can, in turn, overcome the liability of smallness (Wang, 2016).

- Technological capacity: For any business model to be viable and support growth, it has to be technologically viable ( $\mathrm{D}^{\prime}$ souza, 2016). Therefore, technical capability can be a necessity to support business growth, especially in mechanised food processing.

- Market regulations: for instance, high tax rates, can reduce firms' internal finances. This can discourage SMEs from growing to become visible to governmental officials, as this can likely lead to an increase in the cost of operating (Bouazza et al., 2015).

Therefore, a field study is conducted that will also further explore the importance and effectiveness of such a factor in business development success. 
Table 4: Matrix of influential factors on business development in SMEs.

\begin{tabular}{|c|c|c|c|c|c|c|c|c|c|c|c|}
\hline Factors & $\begin{array}{c}\text { Forsman } \\
(2008)\end{array}$ & $\begin{array}{l}\text { Teece } \\
(2010)\end{array}$ & $\begin{array}{r}\text { Rainey } \\
(2010)\end{array}$ & $\begin{array}{c}\text { Sørensen } \\
\text { (2012) }\end{array}$ & $\begin{array}{c}\text { Kajanus, } \\
\text { et al., } \\
\text { (2014). }\end{array}$ & $\begin{array}{l}\text { Wang, } \\
\text { (2016) }\end{array}$ & $\begin{array}{c}\text { Bouazza, } \\
\text { et al } \\
(2015)\end{array}$ & $\begin{array}{l}\text { Achtenhagen, et } \\
\text { al, (2017) }\end{array}$ & $\begin{array}{c}\text { D'Souza } \\
\text { (2016) }\end{array}$ & $\begin{array}{l}\text { Yusof } \\
\text { et. al., } \\
\text { (2017) }\end{array}$ & $\begin{array}{c}\text { Influential } \\
\text { Factors }\end{array}$ \\
\hline Value proposition & + & + & & + & + & & & + & + & & High \\
\hline $\begin{array}{l}\text { Market } \\
\text { penetration/sales }\end{array}$ & & + & & + & & + & & + & + & + & High \\
\hline Cost & & + & & & + & + & & + & + & & High \\
\hline Profit & + & + & + & + & + & & & + & + & & High \\
\hline Competition & & + & + & + & + & & & & & & High \\
\hline Market size & + & + & & + & & & & & + & & High \\
\hline $\begin{array}{l}\text { Entrepreneurial } \\
\text { competencies }\end{array}$ & & + & + & + & + & & + & + & & + & High \\
\hline Financing & & & + & & & + & + & & & & Medium \\
\hline Network partners & & + & + & & & & & + & + & & Medium \\
\hline Barriers to entry & + & & & + & & & & & & & Medium \\
\hline Market regulations & & + & & & + & & + & & & & Medium \\
\hline Business abilities & + & & & + & & & & & & & Medium \\
\hline External environment & & & & & + & & + & & & & Medium \\
\hline $\begin{array}{l}\text { Human resource } \\
\text { capacities }\end{array}$ & & + & & + & & & & + & + & & High \\
\hline Customers & & & + & & & & & + & + & & Medium \\
\hline Suppliers & & & & & & & & & + & & Low \\
\hline Technological capacities & & & & & & & + & & + & & Low \\
\hline Delivery time & & & & & & & & & & + & Low \\
\hline Innovation & & & & & & & & & & + & Low \\
\hline Lean manufacturing & & & & & & & & & & & Low \\
\hline
\end{tabular}




\section{The Gulf Cooperation Council (GCC) market situation}

The GCC is an economic and political alliance which was formed to strengthen cooperation and reinforce the links between its member countries (Martini et al.; 2016). Its countries represent nations with fast-growing populations. However, the GCC nations import the majority of the food which they consume (Alpen Capital, 2015). Even food products made locally rely heavily on foreign employment (Yaqoob, 2011). What is more, the tourism sector of the GCC countries is also growing significantly. The increase in tourists visiting the GCC region is also causing a parallel growth in its hospitality sector, and indirectly, also causing the growth of the GCC's food and beverage sector (Nagraj, 2013; Al Masah Capital, 2014; Algethami, 2015). Furthermore, other factors also contribute to the increasing food consumption in the GCC region, such as population growth, rising disposable income levels, and changing consumption patterns (Malek, 2014; Napier, 2014).

Presently, it is considered impossible for the GCC to grow all the food it needs, primarily due to its weather conditions and the limited water resources available in the region (Al-Farra, 2015; FAO, 2015). Consequently, this lack of water affects the amount of agriculture which can be done in the region. In 2012, approximately 30 million metric tons of food was imported into the GCC region as compared to the approximately 10 million metric tons of food that were locally produced (Alpen Capital, 2015). As a result, focusing more on local agriculture for all types of crops, to minimize imports, does not seem like a plausible option, as that will also have a detrimental effect on the water supply of these nations.

It is therefore evident that the market in the GCC area is subjected to rapid change, and this will require companies also to adapt their businesses, to meet the growing demands and competitions. Furthermore, if such companies are to succeed in exploiting the opportunities provided by the changing environment and at the same time cope with its threats, their strategies must be aligned with the new market realities. With minimal research on business development in the GCC food sector, this paper aims to fill the gap by researching factors affecting business development in the region.

Given the advantages of the BMC, the next section will review the particular characteristics of this studies' target market (GCC), in order to develop a suitable business model canvas for the region's food and beverage industry SMEs.

The industrial perspective of influential factors on business development: Analysis and findings

This section presents the data analysis of the findings from the industrial field study. It mainly focuses on the questions that relate to the influential factors of business development, challenges in business development, and business development models, as they relate to the GCC food sector.

For each survey item presented, the questions were used to evaluate the perceived effectiveness and importance of each activity. These were presented as an activities list, with a five scale Likert type response representing importance and effectiveness. So, any score from 3.5 to 5 indicate relative importance or effectiveness, while less than 3.5 indicates not unimportance or not effective.

Influential factors affecting the decision to grow your business or expand to new market

During the field of study, the researchers observed several issues that influence business development among the SMEs of the GCC region. Firstly, it was observed that all the identified drivers from the literature review are considered important by practitioners in the industry. Nevertheless, the most important drivers for business development were shown to be 'increasing sales' and 'entering new markets.

It is good to see the companies are aware of these drivers; however, executing these activities to achieve business growth has several challenges. One of such key challenges identified is 'access to finance'. The next research item investigated how the companies address this issue.

\section{Main challenges in access finance to support business growth}

Access to finance is one of the most significant factors reported both in the literature review and by the business, as a barrier to their growth and expansions. This field study specifically asked what challenges the business faced with accessing finance. The result showed that the only challenge they have, stopping them from access finance is their lack of formal 'business planning capability'. 


\section{Key activities currently undertaken as part of business development}

The field study also showed that most of the companies were not aware of the importance of some key activities, while these are activities that they should be carrying out in their business development. It was evident from the way the majority of the respondent responded, where they rated some important activities as having low importance- only making a new product, increased rate of production and 'new market research beyond the typical commercial area' were identified of having high importance in the region.

In regard to how they view the effectiveness of the listed key business development activities, only new product development and 'new market research beyond the typical commercial area' were considered effective in helping their business grow.

Influential factors affecting the execution of business development

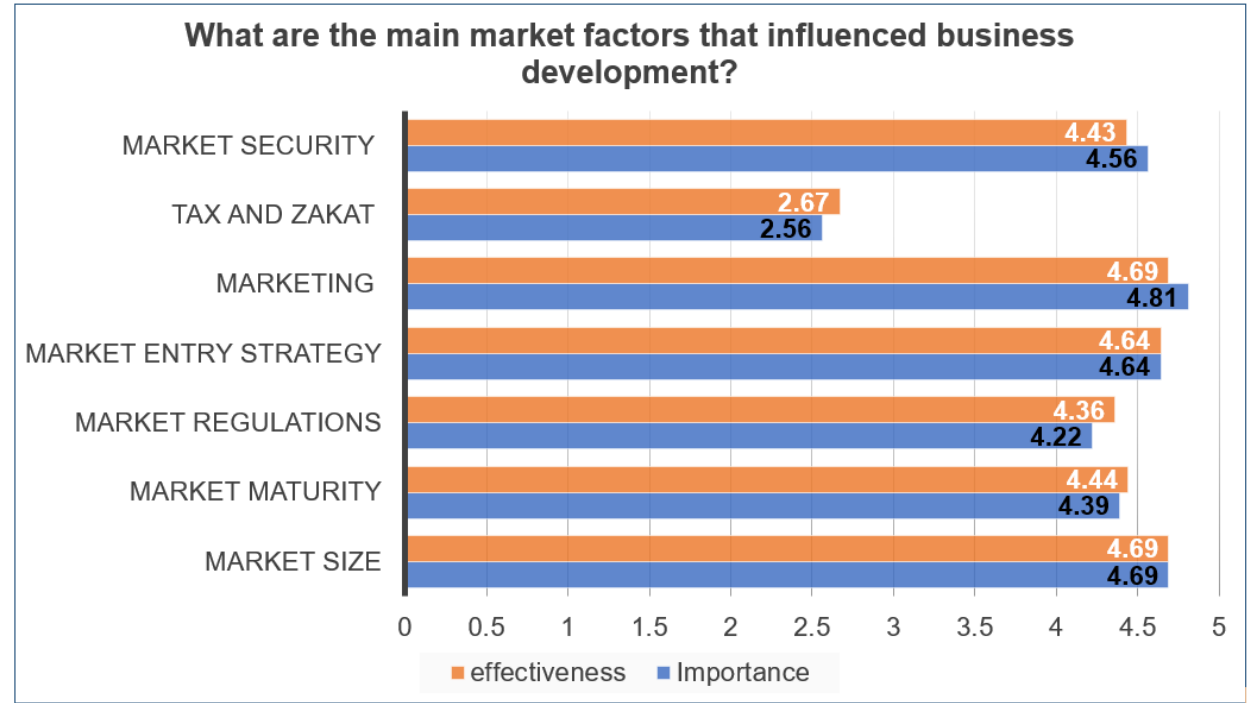

Figure 1: Market factors influencing business development among food SMEs in the GCC

The results also showed that all the business modelling elements were considered of high importance. Specifically, marketing and market size were considered to be of the utmost importance. On the other hand, Tax and Zakat were considered insignificant. Except for Tax and Zakat, all the elements were considered to have a high impact on business performances. Marketing and market size were specifically, reported to have the most significant impact on business development activities.

Influential capabilities needed for business development

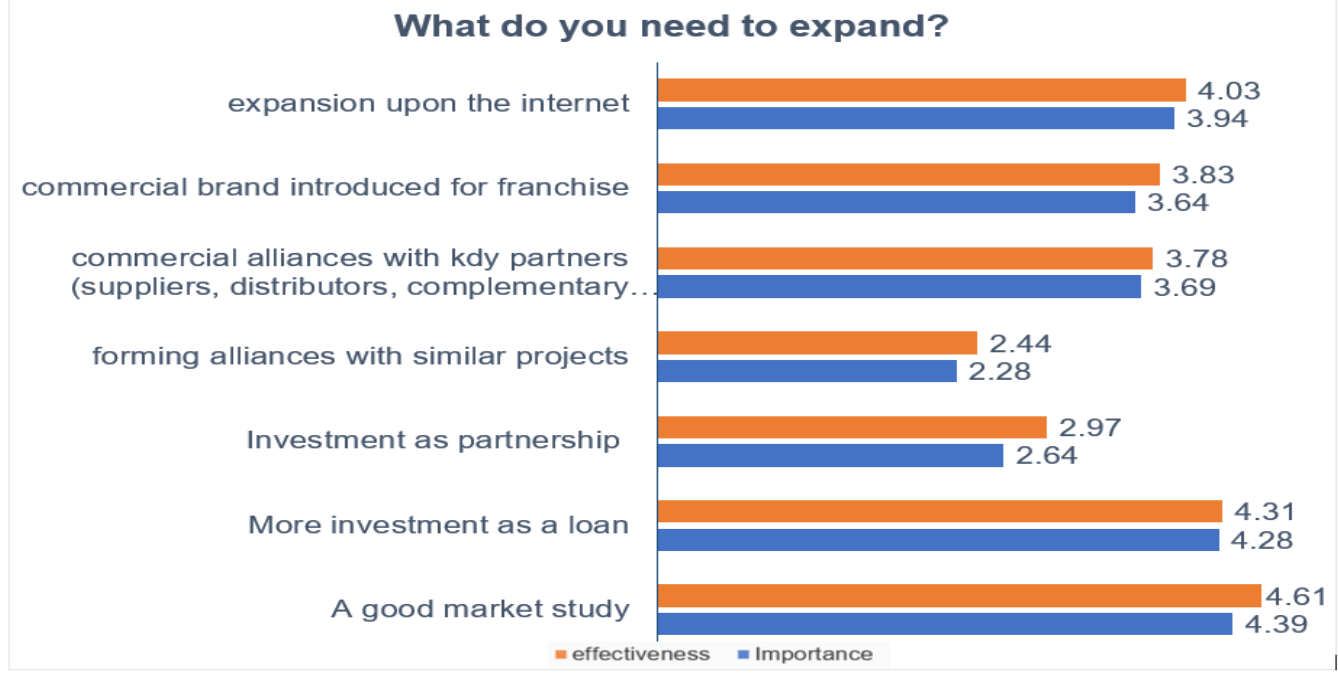

Figure 2: Factors affecting growth and business development among food processing companies 
The results also showed that most of the respondents were not aware of the other key elements that are involved in business development apart from market study, loan as an investment, and online growth which were considered as important capabilities, in which they needed to grow their business.

In terms of effectiveness, only market study and 'investment as a loan' were considered to have the most significant impact on their business growth.

\section{Discussion of findings of Influential factors of business development}

The following is an analysis and discussion of each of the influential factors identified from the field study, describing how they will have an impact on business development, business sustainability and growth of SMEs in the food sector of the GCC.

Specifically, the factors observed from the field study are listed below.

1. Increasing sales

2. Lack of a framework or a process for business development

3. Identifying the needs in the market

4. Meeting demand for more of the same product

5. Making new products

6. Newmarket research beyond the typical commercial area

7. Marketing

8. Market study

9. Loan as investment

10. Business planning capability

11. Availability of competitively priced raw agricultural products

As the aim of this study is to offer a business development framework or business model, which can guide the SMEs of the food sector in the GCC to carry out their business development, the factors are thus further analysed as they relate to the $\mathrm{BMC}$, and then grouped into similar themes for ease of understanding.

1. Increasing sales: this aspect is considered the key goal of business development activities among most firms; it is the results of various other activities including-improvement of the production process, increased access to key resources (including the raw materials used in production), or due to an increase in the number of product lines from new product developments. It is, therefore related to key activities, resources, and value proposition elements of the BMC.

2. Identifying the need in the market: this is related to the value proposition and customer segment of the BMC. It requires the firms to identify who are their key customers and also how best to satisfy them.

3. New product development: this aspect is also associated with the value proposition aspect of the business. It involves identifying demands and gaps in the market, by means of research and development, so as to introduce new products to the market. Therefore, this will also involve customer segmentation to identify the key customers and then defining the value proposition, so as to provide products that satisfy the customers.

4. Market study: this is also similar to 'new market research' and is related to the customer segmentation and value proposition elements; it involves researching and documentation of established markets for the business products.

5. Meeting demand for more of the same product: this is chiefly associated with the key resource's element of the BMC; it requires access to finance so as to acquire increased production capacity, and also to help in acquiring more raw materials. This factor is also associated with the distribution channel that is needed to make the products available to the customers.

6. Newmarket research beyond the typical commercial area: this is also associated with key activities and customer segmentation elements of the BMC. it involves scanning the market to establish more customer base - both locally and internationally, so as to increase the sales from the business.

7. Marketing: this is also associated with the customer relationship' element of the BMC. It requires the business to promote the company's product to the customers. 
8. Loan investment: this refers to access to finance to support all of the business growth activities. It is also needed to access raw materials and other key resources required by the business. It is therefore related to the key resources' element of the BMC.

9. Business planning capability: this aspect is unique to the business model, as it encompasses all elements of the BMC. It is the final documentation of all the elements of the BMC and their interaction. It is carried out before the onset of a business or at the onset of a business's new activity, so as to ensure that the business succeeds. In this context, it is an activity carried out as a key requirement to access investment, loan and other financial instruments, to allow the business to access the needed resources and capabilities to start-up or grow.

10. Availability of competitively priced raw agricultural products: This is one of the most important 'key resources' of the business. The availability of raw materials at competitive prices allows the business to provide lower prices to the customers as well as earn more in revenue and profit. It also helps the company meet increased demand and an increase in sales.

From the analysis of the results and findings, as elaborated above, three common themes are identified.

The first two relate to the elements of the BMC, which includes customer segmentation and developing the right value proposition. The last part is related to the entire BMC elements, as it relates to documenting it as a business plan. Customer segmentation stands out here, as it was NOT one of the most highly cited in the literature in Table 1, and even far less in Table 4.

In regard to the first two themes, they are the key starting points of any business modelling activity (Osterwalder et al., 2015). The responses within the themes show that there is a hardship defining the value concept required. This implies that they have a challenge of establishing a 'product-market fit'. This supports previous findings that the value proposition and customer segmentation interact mainly in developing the product-market fit (Osterwalder et al., 2015).

Product market fit can be defined to be: the fit between the offering and value provided, to the market requirements created by the needs of customers; and this fit creates the first step in formulating a successful business model (Andreessen, 2007).

If no fit is achieved at any level, then the product or service offered is not going to satisfy the market, and ultimately the business will not survive or thrive.

It's understandable that the results will show product-market fit as a challenge in the GCC; as has been identified in the study, the region is experiencing rapid changes in customer demand as a result of tourism, change in tastes and lifestyle (Algethami, 2015;Malek, 2014; Napier, 2014). This will also mean changes in the type of food customer's desire, as well as how they would like to access their food. All these changes have several implications on the SMEs in terms of 'what' products or service to offer, and 'how'.

Lastly, business planning here as a theme relates to the instrument used to access to finance. As can be seen, access to finance (or loan) as a key factor in business development, is linked to the ability to conduct market research and develop a business model. The business plan is the final product of the business modelling activity, which documents the overall business model, including what it seeks to achieve and how (Türko, 2016).

For new or cash strapped companies, the business plan is what they use to apply for a loan and other financial instruments. In the case of established companies seeking to grow, the business plan is the basis of decision making, with which management can inject finance to new activities (Jukova et al., 2019).

However, despite being a popular and widely used tool for business development, the BMC still has its limitations and criticism, as was highlighted previously. As regards its effectiveness to support SMEs in the GCC, so that they can achieve product-market fit, the key weakness as identified in this study needs to be addressed. Firstly, is the BMC's lack of explicit modelling method, whereby, there are no instructions explicitly defining the approach to developing the BMC elements (Aarntzen, 2016). As such, it cannot easily be translated into practice by a new or inexperienced manager (Solaimani and Bouwman, 2012). This is more critical in regard to the development of the value proposition among SMEs. 
Therefore, the BMC must be complemented with more information, so that even a novice SME manager can be guided through step by step process of what to do in developing their business model. This supports previous studies of Ching and fauvel (2013).

Secondly, as the business development process using the BMC is not a linear process, but goes back and forth, until the right product-market fit is achieved, among the shortcomings of BMC is that it mixes different levels of abstraction among different elements. Level of abstraction is one of the reasons that business owner with no business development experience or education, cannot understand how to go about developing their business model, or how to fill up the various boxes of the BMC (Kraaijenbrink,2012). This makes it more imperative that a step by step guide be provided to support decision making in developing the BMC for SMEs in the GCC.

\section{Conclusion}

\section{Contribution of this paper}

The findings from this study have made it obvious, that SMEs in the GCC food sector need to have a clear business model as the basis of their business development, in order to start up their business or to grow it. They also need a business model to run their businesses. This paper has highlighted the importance of the influential factors of business development among the GCC food SMEs, and how they impact the decision-making process of the business owners, in seeking to meet their business development objectives. Such factors have been identified through extensive literature review and subsequent analysis of the data captured from the industrial field study. The understanding of these influential factors would provide a knowledge base for SMEs in the food sector of the GCC, so they can know what the most important considerations and activities required to help them achieve their growth targets are. It will also enable them to identify the pitfalls and challenges they should watch out for.

However, despite having identified the influential factors of business development, such factors need to be presented in a way that shows how they interrelate with other business activities, and how they can be communicated so that even a novice in the business or the organisation can apply it. This is what business models such as the business model canvas (BMC) are intended for. It was highlighted that the BMC is the most suitable to be adopted for this purpose, especially for the SMEs of the GCC food sector. Therefore, the identified factors have also been explained as they relate to the various elements of the BMC.

\section{Managerial Implications}

This study has provided some fascinating insights into the factors that influence business development among the food SMEs of the GCC.

All the factors identified are shown to be related to the market research phase, the product development phase, and subsequent documentation of the business model and plan. So, the most important factors affecting business development success among the food SME in the GCC are the actual customer identification, and the requirements definition, towards the development of the right value proposition

From a practical perspective, the key influential factors are a reflection of key BMC elements. Two key elements were identified within which the influential factors were mostly associated with. These are the elements of the value proposition and customer segmentation. The interplay of the two elements helps a business achieve 'product-market fit'.

The findings have managerial implications in a practical sense. It shows that the business model is of high relevance when it comes to the business development of the food SME in the GCC, however, in applying the BMC to the SMEs, it needs to be improved, so that it offers a guided step by step instructions, to how they can segment their customer and develop their value propositions; thereby achieving a product-market fit.

Therefore, to enhance the usefulness of the BMC, what is needed is subtitles within the various elements, and these should describe issues the manager should consider, in making product development decisions to fit the available market demands. 
However, these details need to be presented in a way that shows how they interrelate with other business activities, as this will help maintain the visual representation strength of the BMC so that it can be communicated to even novice business managers.

\section{Limitation and Suggestion for Future Research}

Regarding the limitations of this study, firstly, the sampling was judgmentally selected, where some biases may have existed. The fact that most of the subjects are based in the KSA may be considered such a bias, yet this cannot be confirmed because of the nature of the study. One rationale to explain this would be the fact that the KSA has a very developed SMEs ecosystem, compared to other countries in the GCC, second only to the UAE.

The second limitation is related to the representativeness of the sample. The sample size was small due to the exploratory nature of the first part of the research. Nevertheless, when the findings are proposed based on the collected data, the representativeness issue is a limitation of this study, binding the academic and industrial parts of this research together.

Furthermore, further research is required to see what knowledge can be captured from experienced practitioners in the industry, which can form the subtitles to guide even novice business owners and managers. Further studies should also seek how this knowledge can be presented, in such a way to make it effective for business development. In order words, further studies should asses how the BMC can be integrated with the knowledge into a holistic model.

\section{Reference}

Aarntzen, R. (2016). The Use of Frameworks in Business Model Development (Master's thesis, University of Twente).

Achtenhagen, L., Ekberg, S., \& Melander, A. (2017). Fostering growth through business development: Core activities and challenges for micro-firm entrepreneurs. Journal of Management $\mathcal{E}$ Organization, 23(2), 167-185.

Ahmedova, S. (2015). Factors for increasing the competitiveness of small and medium-sized enterprises (SMEs) in Bulgaria. Procedia-Social and Behavioral Sciences, 195, 1104-1112.

Al-Debei, M.M. and Avison, D., 2010. Developing a unified framework of the business model concept. European Journal of Information Systems, 19(3), pp.359-376.

Al-Farra, T. (2015). Water Security in the Gulf Region. Retrieved from Al Jazeera Cent. Stud: http://studies.aljazeera.net/en/dossiers/2015/03/20153318534835257.html (last accessed 26.09.18).

Al Masah Capital. (2016). GCC Food Service Sector. Retrieved from Al Mash Capital: http://www.almasahcapital.com/images/reports/report-142.pdf (last accessed 26.09.18).

Alpen Capital. (2015). GCC Food Industry. Retrieved from:

"https://www.yumpu.com/en/document/read/40198091/gcc-food-industry-alpen-capital" https://www.yumpu.com/en/document/read/40198091/gcc-food-industry-alpen-capital (last accessed 26.09.18).

Algethami, S. (2015, April 28). GCC food consumption to grow by 3.5\% annually by 2019. Retrieved from Gulf News: https://gulfnews.com/business/retail/gcc-food-consumption-to-grow-by-35-annually-by-2019-1.1500611\} (last accessed 28.08.19).

Altinay, L., Madanoglu, M., De Vita, G., Arasli, H., \& Ekinci, Y. (2016). The interface between organizational learning capability, entrepreneurial orientation, and SME growth. Journal of Small Business Management, 54(3), 871-891.

Amentie, C., Negash, E., \& Kumera, L. (2016). Barriers to growth of medium and small enterprises in developing country: Case study Ethiopia. Journal of Entrepreneurship and Organization Management, 5, 190.

Andreessen, M. (2007). Product/Market Fit: The only thing that matters is getting to product/market fit, Unpublished manuscript, Stanford University. Retrieved from Stanford University: https://web.stanford.edu/class/ee204/ProductMarketFit.html (last accessed 28.08.19).

Baden-Fuller, C., \& Mangematin, V. (2013). Business models: A challenging agenda. Strategic Organization, 11(4), 418427.

Bouazza B.A., Ardjouman, D. \& Abada, O. (2015). 'Establishing the Factors Affecting the Growth of Small and Mediumsized Enterprises in Algeria.' American International Journal of Social Science, 4(2): 101-115.

Chesbrough, H., \& Rosenbloom, R. S. (2002). The role of the business model in capturing value from innovation: evidence from Xerox Corporation's technology spin-off companies. Industrial and corporate change, 11(3), 529555.

Ching, H. Y. \& Fauvel, C. (2013). Criticisms, Variations and Experiences with Business Model Canvas, European Journal of Agriculture and Forestry Research, Vol.1. No.2, pp. 26 -37.

Coes, D. H. (2014). Critically assessing the strengths and limitations of the Business Model Canvas. Unpublished Master's Thesis. University of Twente, The Netherlands. http:// essay.utwente.nl/64749/1/Coes_MA_MB.pdf 
Demil, B. and Lecocq, X., (2010). Business model evolution: in search of dynamic consistency. Long range planning, 43(2), pp.227-246.

Drakulevski, L., Nakov, L. and Iliev, F. (2014). Sports Management and Opportunities for Professional Development". Research in Physical Education, Sport \& Health, 3(1).

D'Souza, A., Wortmann, H., Huitema, G. and Velthuijsen, H. (2016). A business model design framework for viability; a business ecosystem approach. Journal of Business Models, 3(2).

FAO. (2002). The State of Food and Agriculture 2002. Retrieved from Food and Agriculture Organization Of The United Nations: http://www.fao.org/tempref/agl/AGLW/ESPIM/CD-ROM/documents/2B_e.pdf (last accesed, 28.98.2009)

FAO. (2015). The State of Food and Agriculture 2015. Retrieved from Food and Agriculture Organization Of The United Nations: http://www.fao.org/3/a-i4910e.pdf (last accesed, 28.98.2009)

Fielt, E. (2014). Conceptualising business models: Definitions, frameworks and classifications. Journal of Business Models, 1(1), pp.85-105.

Forsman, H. (2008). Business development success in SMEs: a case study approach. Journal of Small Business and Enterprise Development, 15(3), pp.606-622.

García-Gutiérrez, I. and Martínez-Borreguero, F.J. (2016). The Innovation Pivot Framework: Fostering Business Model Innovation in Startups: A new tool helps entrepreneurs design business models by identifying the sources of competitive advantage embedded in an innovation. Research-Technology Management, 59(5), pp.48-56.

Golnam, A., Ritala, P. and Wegmann, A. (2014). Coopetition within and between value networks-a typology and a modelling framework. International Journal of Business Environment, 6(ARTICLE), pp.47-68.

Gupta, P. D., Guha, S., \& Krishnaswami, S. S. (2013). Firm growth and its determinants. Journal of innovation and entrepreneurship, 2(1), 15.

Hamel, G. (2001). Leading the revolution. Strategy \& Leadership.

Hoffmann, F. E. G. (2013). Visual Business Model Ideation (Doctoral dissertation).

Hsu, S. Y., Woodside, A. G., \& Marshall, R. (2013). Critical tests of multiple theories of cultures' consequences: Comparing the usefulness of models by Hofstede, Inglehart and Baker, Schwartz, Steenkamp, as well as GDP and distance for explaining overseas tourism behavior. Journal of Travel Research, 52(6), 679-704.

Johnson, M. W., Christensen, C. M., \& Kagermann, H. (2008). Reinventing your business model. Harvard business review, 86(12), 57-68.

Jukova, E. E., Ilina, I. Y., Gundarin, M. V., Potekhina, E. V., Misanova, I. N., \& Zotova, A. I. (2019). Planning a new business: typical mistakes of a business plan in the service sector. Journal of Environmental Management and Tourism, 10(2), 441-447.

. Kajanus, M., Iire, A., Eskelinen, T., Heinonen, M., \& Hansen, E. (2014). Business model design: new tools for business systems innovation. Scandinavian Journal of Forest Research, 29(6), 603-614.

Kaplan, S. (2012). The business model innovation factory: How to stay relevant when the world is changing. John Wiley \& Sons.

Kor, Y. Y., Mahoney, J. T., Siemsen, E., \& Tan, D. (2016). Penrose's The Theory of the Growth of the Firm: An exemplar of engaged scholarship. Production and Operations Management, 25(10), 1727-1744.

Kraaijenbrink, J. (2012, July). What are the shortcomings of the business model canvas? Business Model innovation hub. [Online] [Accessed on 19th September 2016] http://businessmodelhub. com/forum/topics/what-aretheshortcomings-of-the-business-model-canvas.

Kumar, R. (2017). Targeted SME Financing and Employment Effects: What Do We Know and What Can We Do Differently? World Bank.

Lucassen, G., Brinkkemper, S., Jansen, S., \& Handoyo, E. (2012, June). Comparison of visual business modeling techniques for software companies. In International Conference of Software Business (pp. 79-93). Springer, Berlin, Heidelberg.

Malek, C. (2014). Growing population will force UAE to face up to food security. Retrieved from The National: http:/ / www.thenational.ae/uae/growing-population-will-force-uae-to-face-up-to-food-security (last accessed 15.06.19).

Martini, J., Wasser, B., Kaye, D. D., Egel, D., \& Ogletree, C. (2016). The Outlook for Arab Gulf Cooperation. Rand Corporation.

Massa, L., \& Tucci, C. L. (2013). Business model innovation. The Oxford handbook of innovation management, 20(18), 420441.

Morris, M., Schindehutte, M., \& Allen, J. (2005). The entrepreneur's business model: toward a unified perspective. Journal of business research, 58(6), 726-735.

Nagraj, A. (2013). GCC Food Consumption to Hit \$106bn by 2018. Retrieved from Gulf Business: https://gulfbusiness.com/2013/02/gcc-food-consumption-to-hit-106bn-by-2018/〉 (last accessed 08.03.19). 
Napier, M., 2014. Capitalising on The Middle East's Rising Food Demand. Retrieved from Gulf Business: https://gulfbusiness.com/capitalising-middle-easts-rising-food-demand (last accessed 28.03.19).

Nason, R. S., \& Wiklund, J. (2018). An assessment of resource-based theorizing on firm growth and suggestions for the future. Journal of Management, 44(1), 32-60.

O'Cass, A., \& Sok, P. (2013). Exploring innovation driven value creation in B2B service firms: The roles of the manager, employees, and customers in value creation. Journal of Business Research, 66(8), 1074-1084.

Osterwalder, A., Pigneur, Y., \& Tucci, C. L. (2005). Clarifying business models: Origins, present, and future of the concept. Communications of the association for Information Systems, 16(1), 1.

Osterwalder, A., \& Pigneur, Y. (2010). Business model generation: a handbook for visionaries, game changers, and challengers. John Wiley \& Sons.

Osterwalder, A., Pigneur, Y., Bernarda, G., \& Smith, A. (2015). Value proposition design. Campus Verlag.

Rainey, D. L. (2010). Sustainable business development: inventing the future through strategy, innovation, and leadership. Cambridge university press.

Reim, W., Parida, V., \& Örtqvist, D. (2015). Product-Service Systems (PSS) business models and tactics-a systematic literature review. Journal of Cleaner Production, 97, 61-75.

Roome, N., \& Louche, C. (2016). Journeying toward business models for sustainability: A conceptual model found inside the black box of organisational transformation. Organization E Environment, 29(1), 11-35.

Sarwoko, E., \& Frisdiantara, C. (2016). Growth determinants of small medium enterprises (SMEs). Universal Journal of Management, 4(1), 36-41.

Solaimani, S., \& Bouwman, H. (2012). A framework for the alignment of business model and business processes. Business Process Management Journal.

Sørensen, H. E. (2012). Business Development: a market-oriented perspective. Chichester: Wiley.

Staniewski, M. W. (2016). The contribution of business experience and knowledge to successful entrepreneurship. Journal of Business Research, 69(11), 5147-5152.

Storey, D. J. (2014). Understanding the small business sector: reflections and confessions. Swedish Entrepreneurship Forum.

Teece, D. J. (2010). Business models, business strategy and innovation. Long range planning, 43(2-3), 172-194.

The World Bank, 2015. World Development Indicators -World Data Bank. Retrieved from The World Bank: http://databank.worldbank.org/data/reports.aspx?source=world-development-indicators (last accessed 08.08.19).

Türko, E. S. (2016). Business plan vs business model canvas in entrepreneurship trainings, a comparison of students' perceptions. Asian Social Science, 12(10), 55-62.

Wang, Y. (2016). What are the biggest obstacles to growth of SMEs in developing countries? -An empirical evidence from an enterprise survey. Borsa Istanbul Review, 16(3), 167-176.

Wrigley, C., \& Straker, K. (2016). Designing innovative business models with a framework that promotes experimentation. Strategy E Leadership.

Yaqoob, T., 2011. Imports raise food security flag in UAE. Retrieved from: The National:

http:/ / www.thenational.ae/news/uae-news/imports-raise-food-security-flag-in-uae\}_(last accessed 08.08.19).

Yip, G. S. (2004). Using a strategy to change your business model. Business strategy review, 15(2), 17-24.

Yusof, S. W. M., Jabar, J., Murad, M. A., \& Ortega, R. T. (2017). Exploring the cultural determinants of entrepreneurial success: The case of Malaysia. International journal of advanced and applied sciences, 4(12), 287-297.

Zott, C., \& Amit, R. (2010). Business model design: an activity system perspective. Long range planning, 43(2-3), 216226. 